\title{
DECOLONIAL PEDAGOGICAL PRACTICES: ENGAGING WITH RANCIĖRE
}

\author{
D. J. v. R. Postma
}

Department of Educational Foundations

University of South Africa

Pretoria, South Africa

e-mail: postmdj@unisa.ac.za

\section{ABSTRACT}

The 2015/6 student protests in South Africa questioned the 1994 postcolonial settlement by drawing attention to the demands of decoloniality. The processes of decoloniality are characterised by an openness to pedagogies, epistemologies and forms of governance that promote a plurality of becomings. In order to investigate how educational practices could contribute towards decoloniality, this article draws on Rancière's notion of "equal intelligence". It is argued that this notion of radical equality could assist educators to redefine themselves and their role in emancipatory and decolonial education. This role avoids the extremes of the authoritarian educator on the one hand, and the egalitarian educator, on the other. "Equal intelligence" makes possible a pedagogical space which demands of the student to use his/her intelligence to generate knowledge that does not reproduce a hegemonic tradition. Equality is not the result of an educational intervention, but a presumption that shapes the pedagogical relation as such. This applies also to decolonisation: The presumption of equal intelligence is a powerful way to decolonise the mind. In this process the educator has an important role to play to create a context where the will and the freedom to participate in the construction of powerful knowledge is kept alive.

Key words: education, emancipation, equal intelligence, decoloniality, Rancière

\section{INTRODUCTION}

The 2015/6 student protests in South Africa questioned the postcolonial settlement by drawing attention to the demands of decoloniality. Demands were made about economic access, the cultural and symbolic transformation of institutions, the decolonisation of the curriculum, and socially just pedagogies. While the protests are something of the past, the persistent issue to address coloniality remains. Persistent attention to decoloniality is needed in the light of the distracting institutionalised programmes of transformation, the conflation of decoloniality with discourses of social justice and social cohesion and the tsunami of neoliberal reterritorialization of subjectivities.

The occurrence of these protests on university campuses raises the question about the role 
of education in the radical democratic renewal of society (Langa 2017; Mabasa 2017). Pedagogical practices, consisting of social relations and knowledge transactions, have been at the heart of coloniality through the establishment of hierarchies and social divisions. The student protests pointed out that the pedagogical practices were still deeply entrenched within the "colonial matrix of power" (Quijano 2000, 550) where the Eurocentrism of knowledge leads to the epistemicide (Santos 2014) of others. Accordingly, the participation of students (of difference) in the generation of knowledge is conditional on their successful socialisation within dominant pedagogical knowledge practices. Through the pedagogical relation students are introduced to and orientated into ontic, symbolic and epistemic orderings which entail among others the production and maintenance of dominant ideas, values, dispositions, epistemic processes and criteria. They experience these orderings as deeply alienating and denigrating at a crucial time when their own intellectual powers are developing.

The focus here on pedagogy is to be distinguished from decolonial curriculum-debates (such as Le Grange 2016) which deal with the inclusion of content from sources other than the dominant West (indigenisation and afrikanisation). The curriculum debates do not necessarily question the objectivist nature of knowledge and may simply add a different kind of content that again has to be transmitted and assessed. The pedagogical question does not deal with the nature of knowledge but rather focuses on the processes of knowledge generation. It deals with the relations between educator and student and the contexts of knowledge transactions.

The postcolonial era is characterised by new forms of coloniality which is about the expansion, intensification and maintenance of the colonial geographic divisions through which capital/power is accumulated at the cost of the world majority. The generation of knowledge within coloniality (including neocolonalism and neoliberalism) serves the dominant interests. In neoliberal pedagogies active subjectivities are produced in accordance with the demands of competition, accountability, consumption and standardisation. Commodified academic and professional outcomes that meet the "demands of the economy" determine these pedagogies. The produced subjectivity of client/student demands packaged content ready for consumption, and the educator is reduced to the role of a coach for the marketized society.

The matrix of power of coloniality, neoliberalism and late capitalism seems impenetrable and total as it encompasses the spheres of economy, governance, education, culture and sport. It should, however, be realised that any configuration of power is a fragile assemblage (Callon and Latour 1981) that is simultaneously maintained and subverted. Since the production of subjectivities in education is one of the important ways in which such matrices of power are maintained, it is also the terrain where it should be "unseamed".

The question this article wants to address is therefore how emancipated or decolonial 
subjectivities could be enabled through pedagogical practices. What kind of pedagogical relation could contribute towards decolonial education? In reconsidering pedagogy, the focus of this article is not so much on the negative process of de-colonisation, but rather on the positive side: How could subjectivities of freedom be enabled?

The paradox should not be missed: How is it possible to enable emancipation in a way that does not already compromise the very process of enablement? Pedagogies of emancipation grapple with the two extremes: One the one hand the view of the educator as the liberator, and on the other hand the absence of the educator as a learning companion. The problematic role of the educator in emancipatory education is enhanced by their ignorance. As intellectuals, they are part of the middle class which render them ignorant of the situated knowledges of others; as products of Western education, most of them are ignorant of any "other" (Dabashi 2015; Said 2003); there is also an inevitable generational gap that leaves them ignorant of the experiences of the "new ones" (Arendt 1998). A critical self-awareness of these ignorances could have a debilitating effect on emancipatory educators shunted into a side line of observers or emphathisers as has been the case during the student protests.

This article is driven by a belief that "ignorant" educators have a very important role to play in emancipatory education. It draws on Rancière's notions of radical equality and the ignorant schoolmaster in an attempt to imagine decolonising pedagogical practices where the educator is not paralysed by an inappropriate notion of equality, or by a sense of irrelevance.

While the use of a western philosopher in the debate on decoloniality requires justification, this article does not aim to "apply" Rancière's ideas, but rather to engage with them. If Rancière is respected as an "ignorant schoolmaster" his ideas could only be translated into a different narrative within a different context. Although Rancière does not address coloniality as such, the basic idea of "equal intelligence" finds appeal in various decolonial thinkers such as Wa Thiong'o and Mignolo. What is new in Rancière's ideas is the way equality is consistently theorised in political and educational contexts. Since Rancière theorises within a particular context, the idea of equal intelligence has to be reterritorialized within the context of decoloniality.

The article also aims to contribute to the growing interest in the work of Rancière in various terrains and particularly in education (Anwaruddin 2015; Biesta 2017; Bingham and Biesta 2010; Galloway 2012; Hallward 2005; Simons and Masschelein 2011; Vlieghe 2016). While many key aspects of education are discussed by these authors, issues of coloniality have not been adequately addressed. This article is therefore an attempt to contribute towards these lines of flight by invoking the contexts of decoloniality and the dilemma of the paralysis of the emancipatory educator in notions of democratic education. Besides its contribution to 
decoloniality, this article explores the important pedagogical role of the ignorant educator.

It follows Anwaruddin's (2015) approach not to compromise Rancière's radical position of equal intelligence. He shows how different anti-oppressive pedagogies of liberalism (justice), critical pedagogy (empowerment), postmodernism (identity), and caring (inclusivity, hospitality) attempt to create a non-threatening environment where students could realise their full potential. He shows, however, that these pedagogies could lead towards stultification since all of them assume inequality where the oppressed relies on the help of others to become equal (Anwaruddin 2015, 739, 740). Overturning this very assumption of inequality is what separates Rancière's position from other emancipatory pedagogies. It is pointed out by Bingham and Biesta (2010) that the very desire to emancipate the other assumes the superiority of the emancipator and actually stultifies the oppressed.

An attempt is made to engage with the ideas of Rancière by arguing that important insights into emancipatory education within the context of decoloniality could be generated. The claim is made that decolonisation in education would be hampered if the pedagogical relations are not radically revised. While the importance of the role of the educator is affirmed, the nature of the role as defined by the presumption of equal intelligence is crucially important for the "decolonisation of the mind[s]" of students.

\section{THE EXPLICATIVE REGIME OF COLONIALITY}

\section{The presumption of inequality}

Rancière finds his inspiration in an incidental discovery of the revolutionary educator and philosopher Jacotot (1770-1840). Jacotot "taught" French to Flemish students in Brussels in the 1820 s while not knowing any Flemish himself. He provided students with the Flemish/French parallel text of Télémaque and requested them to read half the text and then to write in French what they understood. To his surprise they could express their ideas eloquently in French without him having "taught" them anything. From this experience Jacotot inferred that students could learn on their own without the explanations of a teacher, and that the teacher does not need to know the content of what is learnt. The conclusion Jacotot arrived at is that "all men [are] virtually capable of understanding what others had done and understood" (Rancière 1991, 2). Explication is not only unnecessary, but stultifies intelligence.

Rancière's critique is directed towards the "explicative order" (Rancière 1991, 2). With this he has in mind a pedagogy that rests on the belief in the inequality between ignorant and unintelligent students on the one hand, and the knowledgeable and intelligent educator on the other. Because of this gap in intelligence and knowledge the educator has to explain to the 
student before they could understand. The explicative order does not only create the gap, but assumes it from the start. Inequality has to be presumed in order for the educator to be the expert who has to organise, sequence and pace knowledge for the ignorant. Although the purpose of the explicative pedagogy is equality, the presumption of inequality permanently delays equality as an ideal.

\section{Coloniality}

For Rancière, an explicatory regime is not restricted to education, but reproduces the unequal social order. Rancière's critique of the explicative nature of the French society of the 1960's and 1970's could be related to the current world order characterised as neoliberalism (Bingham and Biesta 2010) and as coloniality.

Whereas colonialism refers to the historical process of territorial occupation, coloniality refers to the ongoing and intensive process of geographic, political, economic, cultural and epistemological domination and exploitation. The most stultifying aspect of coloniality as an explicative order is the realisation of inequalities through the denial of the intelligence of the colonised. This aspect has been articulated by authors of decoloniality.

The distinction between colonialism and coloniality entails for Maldonado-Torres the following:

"Coloniality, instead, refers to long-standing patterns of power that emerged as a result of colonialism, but that define culture, labour, intersubjective relations, and knowledge production well beyond the strict limits of colonial administrations. Thus, coloniality survives colonialism. It is maintained alive in books, in the criteria for academic performance, in cultural patterns, in common sense, in the self-image of peoples, in aspirations of self, and so many other aspects of our modern experience. In a way, as modern subjects we breathe coloniality all the time and every day." (Maldonado-Torres 2007, 243).

The emphasis of Wa Thiong'o on the mental and epistemological aspects of colonisation applies to coloniality:

"But its most important area of domination was the mental universe of the colonised, the control, through culture, of how people perceived themselves and their relationship to the world. Economic and political control can never be complete or effective without mental control. To control a people's culture is to control their tools of self-definition in relationship to others .... The domination of a people's language by the languages of the colonising nations was crucial to the domination of the mental universe of the colonised." (Wa Thiong'o 1987, 16).

Intelligence and therefore educational opportunities are defined in relation to compliance with the colonial masters (ibid., 92) or the ability to use English, regardless of achievement in other 
areas (ibid., 12). The denigration of the intelligence of the colonised is the most devastating and lasting effect of colonialism. Whatever is written in the own language is seen to be inferior, while the official texts portray the colonised as inferior and non-intelligent. The "bad" African is the one who questions and resists the colonial beneficence. The texts made available to students are carefully selected "so as not to expose the young minds to dangerous, undesirable and unacceptable moral and political influences" (ibid., 69). Colonial alienation takes two interlinked forms: a distancing of oneself from the reality around; and an identification with that which is most external to one's environment (ibid., 28).

More recently Mbembe $(2016,30)$ argues that the colonisation of pedagogical spaces "is deterring students and teachers from the free pursuit of knowledge". He continues as follows:

"What does it mean 'they are Westernized'? They are 'Westernized' in the sense that they are local instantiations of a dominant academic model based on a Eurocentric epistemic canon. A Eurocentric canon is a canon that attributes truth only to the Western way of knowledge production. It is a canon that disregards other epistemic traditions. It is a canon that tries to portray colonialism as a normal form of social relations between human beings rather than a system of exploitation and oppression." (Mbembe 2016, 30).

Dabashi describes the dominance and exclusivity of Western intelligence as follows:

"The question of Eurocentricism is now entirely blasé. Of course Europeans are Eurocentric and see the world from their vantage point, and why should they not? They are the inheritors of multiple (now defunct) empires, and they still carry within them the phantom hubris of those empires; they believe their particular philosophy is 'philosophy' and their particular thinking is 'thinking', while everything else is - as the great European philosopher Emmanuel Levinas was wont to say - 'dancing'." (Dabashi 2015 - no page number).

This limitation of intelligence is present in colonialist thinking that claims universality and independence from those it colonised. Such claims to universality in Western thinking is identified by Dabashi in his engagement with Žižek. With reference to Gramsci Dabashi comments:

"What in effect Gramsci discovers, as a Southern Italian suffering in the dungeons of European fascism, is what in Brooklyn we call chutzpah - to think yourself the center of the universe, a selfassuredness that gives the philosopher that certain panache and authority to think in absolutist and grand narrative terms.” (Dabashi 2015).

The devastating and paralysing effect of colonisation on thinking is expressed as follows by a group of Palestinians: 
"[W]e are scared of being incarcerated, interrogated, hit, tortured, bombed, killed. We are afraid of living, because every single step we take has to be considered and well-thought, there are limitations everywhere, we cannot move as we want, say what we want, do what we want. Sometimes we even can't think what we want because the occupation has occupied our brains and hearts so terribly that it hurts and makes us want to shed endless tears of frustration and rage." (In Dabashi 2015).

With Dabashi (2015) the coloniality of knowledge could be traced to presumed universality (or truth) of the Western intelligence. Debashi detects such universalistic thinking in Žižek who denies philosophy in the East (of Africa) or intellectual insights during the Arab-Spring.

The denial of speaking in an own language is the terrain where coloniality affects what could be said.

"To speak means to be in a position to use a certain syntax, to grasp the morphology of this or that language, but it means above all to assume a culture, to support the weight of a civilization .... The problem that we confront in this chapter is this: The Negro of the Antilles will be proportionally whiter - that is, he will come closer to being a real human being - in direct ratio to his mastery of the French language." (Fanon 2008, 8).

Coloniality has the effect to undermine the ability to use the own intelligence and to think for yourself. It causes the paralysis of the mind, the will and the courage to be. The mind is not just colonised with foreign ideas as Wa Thiong'o argues, but the ability to think for yourself is affected. In the process passive and unintelligent subjectivities are produced. Coloniality renders the colonised speechless and thoughtless on the one hand and mirror-images of the colonist on the other. Since the colonised mind is emptied, it is dependent on the master's explications. The explicative regime is now a crucial element in knowledge colonisation and epistemicide.

"Unequal exchanges among cultures have always implied the death of the knowledge of the subordinated culture, hence the death of the social groups that possessed it. In the most extreme cases, such as that of European expansion, epistemicide was one of the conditions of genocide." (Santos 2014, 149).

Such an explicative order does not require to be maintained externally since it became selfperpetuating:

"Like time, the explicatory system is nourished by its own children whom it devours as it produces them; a new explication, a new perfecting is born and immediately dies to make room for a thousand others ...." (Rancière 1991, 128).

As a result the processes of coloniality are localized and perpetuated by the colonized 
themselves. In spite of the intention to promote equality, the axiom of inequality perpetuates social inequalities in society as a whole. Coloniality is the pedagogization of society as a whole:

"The task to which the republican hearts and minds are devoted is to make an equal society out of unequal men, to reduce inequality indefinitely. But whoever takes this position has only one way of carrying it through to the end, and that is the integral pedagogicization of society - the general infantilization of the individuals that make it up. Later on this will be called continuing education, that is to say, the coextension of the explicatory institution with society. The society of the superior inferiors will be equal, it will have reduced its inequalities once it has been entirely transformed into a society of explicated explicators." (Rancière 1991, 133, 4).

Coloniality entails not only the killing of knowledge but mainly the killing of the ability to think as equals. The inferior mind of the colonised is verified by the very process of colonisation.

\section{EQUAL INTELLIGENCE}

With Rancière one could imagine that the presumption of inequality is the driving force of coloniality and that the success of the latter serves as verification of the presumption. It therefore seems justified to accept unequal intelligences on the basis of existing inequalities. One could also imagine with Rancière that inequalities will remain in society as long as one starts off with the presumption of inequality. Such a presumption of inequality also underlies the belief that the colonised will catch up once everything is explained and transmitted as presented in discourses and practices of 1"development". The axiom of inequality also underlies reformist approaches to educational equality: Equality in education will be achieved once equal opportunities are provided, resources are equally distributed, and educators are equally qualified. A major mental shift is needed to consider working with a different presumption than that of inequality. What if we start instead with the notion that all intelligences are the same? How will that effect the educational and social order, pedagogy and democracy? What if our notion of decoloniality is based on that of equal intelligence?

This notion of universal equality based on equal intelligence is the central element in Rancière's philosophical and political projects of emancipation. The presumption of equal intelligence means that the same intelligence is present in all individuals irrespective of class, "race", geographical location or gender. Specifically, the same intelligence is present in workers and managers, the learned and illiterate, educator and student, oppressor and oppressed, coloniser and colonist.

Triggered by his experiences of May '68, Rancière departs from the Marxist intellectual tradition and in particular from Althusser's view of the superiority of intellectuals. According to this tradition it is the task of the intellectual to speak on behalf of the silent working class. In 
contrast to the Marxist orthodoxy, Rancière (2012) explores in "Proletarian nights" how the intelligence of workers in the $19^{\text {th }}$ century is not determined by their ideological class position and could not be understood in terms of "false consciousness". He recounts how they express intelligence through poetry where they address issues of inequality and where they counter the demands of the commodity economy. He therefore found that workers' ideas cannot be explained in terms of their class position, that they do not need intellectuals to speak on their behalf and that they are capable to express an equal intelligence. Rancière asserts that "in each intellectual manifestation, there is a totality of human intelligence" (Rancière 1991, 136). Since no field of knowledge or specialised practice entails a higher level of intelligence, the workers' poetry is of equal intellectual value than the analyses of intellectuals. The phrase "everything is in everything" (Rancière 1991, 26) means that the totality of understanding can be investigated through any intelligent human activity whether it is farming, academic work, engineering, physics or workers' labour.

As a presumption equal intelligence cannot be proven. "It's seeing what can be done under that supposition" (Rancière 1991, 46). It is not a truth (intuitive or empirical), but an axiom that requires verification in practice as is the case with the presumption of inequality. While we know what the devastating outcomes of presumption of inequality are, we do not yet know what the effects of the presumption of equality might be. The expectation is, however, that it would contribute towards the multiplication of knowledges and that it would undermine the dominance of one knowledge and of one way of thinking. The hope exists that this might lead towards a more egalitarian world.

Equal intelligence leads to the multiplication of opinions and knowledges without truth claims. Such claims to truth should be avoided since they are part of the explicative order and epistemic domination. The truth, for Rancière is one, and cannot be captured by language which is arbitrary (Rancière 1991, 60). Language is arbitrary in the sense that it fragments the truth. Truth can only be spoken about poetically. While a universal truth is not to be found, an increasing level of complex and diverse mutuality is to be expected when intelligences engage each other. While languages can only express truth poetically, they do so equally. Wa Thiongo's insistence on the use of the own language is therefore important to create the enabling conditions for the realization and verification of equal intelligence. Intelligence is expressed through language and it becomes known to the self and others through language. Emancipation concerns revealing “an intelligence to itself” through language (Rancière 1991, 28).

Once this principle of equal intelligence is accepted, how should inequalities of intelligence be explained? Although equal intelligence is presumed to exist, it is not necessarily exercised equally: 
"There is inequality in the manifestations of intelligence, according to the greater or lesser energy communicated to the intelligence by the will for discovering and combining new relations; but there is no hierarchy of intellectual capacity." (Rancière 1991, 27).

Inequalities therefore exist of the will to intelligence. Will, courage and perseverance are needed to overcome both internal and external barriers to the equal exercise of intelligence. Internal barriers refer to the lack of courage or of faith in the own intelligence, whereas external barriers refer to the dominant beliefs and practices of inequality which feed on such lacks.

The barriers are overcome when the mentally colonised realise that they do not need to be enlightened or conscientised by a liberator. Emancipation is inherently self-emancipation on the basis of the equal exercise of intelligence. This kind of independent thought Mignolo (2009) names "epistemic disobedience". This disobedience is the end of the desire for recognition on terms defined by the dominant. Disobedience refers to the refusal to be subjected to Western epistemic criteria.

Social inequalities are the effect of the presumption of unequal intelligence and not of the unequal exercise of intelligence. Santos shows that the West does not fully exercise its intelligence:

"Would not the historical opportunity for the global North to learn from the experiences of the global South lie precisely here? The truth of the matter is that, after five centuries of 'teaching' the world, the global North seems to have lost the capacity to learn from the experiences of the world. In other words, it looks as if colonialism has disabled the global North from learning in noncolonial terms, that is, in terms that allow for the existence of histories other than the universal history of the West." (Santos 2014, 38).

Even though the global North does not fully exercise its intelligence, it maintains a position of power based on the presumption of superior intelligence. The presumption is a powerful imposition that render the other inferior.

Since the multiplication of narratives (scientific or otherwise) challenges the inequality of the knowledge of the colonized, it brings other knowledge to the surface within an "ecology of knowledges":

"The impetus behind the ecology of knowledges resides in the fact that social struggles, particularly in the global South, are rendering visible social and cultural realities in which faith in modern science is weaker and the linkages between modern science and the objectives of colonial and imperial domination are more visible, while, at the same time, other kinds of non-scientific and non-Western knowledge persist in the social practices of large sectors of the population." (Santos 2014, 300). 
This does not imply a relativism where no distinction could be made between knowledge claims since the

"... alternative to relativism is partial, locable, critical knowledges sustaining the possibility of webs of connections called solidarity in politics and shared conversations in epistemology." (Haraway 1988, 584).

One implication of the knowledge ecology is that there is no epistemic centre typical of Western-style thinking and represented by a critical thinker such as Žižek (according to Dabashi 2015). Such an inappropriate western logic could be detected in the view of decoloniality as "moving the centre" (Wa Thiong'o 1993).

Rancière's interest in education is part of his identification of the conditions for the ongoing political revolutionary transformation of society. Politics take place when subjugated intelligences realise their equality by expressing their opinions. A political society is characterised by dissensus and disharmony caused by the multiplication of opinions. Politics happens when disruptive opinions are expressed through the wilful, consistent and courageous attempts to understand and imagine a different world.

\section{PEDAGOGY}

The presumption of equal intelligence mitigates against prescribed pedagogical processes or educational content. The most important educational question is whether the intelligence of the student is enabled. While this was the case with Jacotot who came across "universal teaching" by change, it is not an act that has to be followed as such. It is up to the emancipated educator to create the particular conditions for the intelligence of students to be enabled.

But, one might ask, why is an educator needed if intelligence is equal? Why do we need to consider pedagogical processes if students can learn by themselves? The main reason is that, while the intelligence of the student is equal to that of the educator, it is not exercised equally. Since students need to acquire the will, the courage and the means to exercise their intelligence, pedagogy is about the creation of the required conditions. Pedagogy is therefore not about the development of intelligence, but rather about exercising it. In the absence of pedagogical prescriptions, one gains from Rancière's engagement with Jacotot a sense of such a pedagogy of equal intelligence.

While intelligence is equal, the will to exercise it and the awareness of its powers might be lacking. Intelligence requires the continual search for an own opinion which does not rest with easy answers. The educator plays a very important role since this search requires the questioning by another intelligence engaged in its own truth-seeking quest. Intelligence is 
impeded when it attempts to proceed in isolation from such others, and when it claims to have arrived at a final truth (such as the coloniser described earlier by Dabashi).

\section{Ignorance of the educator}

For the intelligence of the student to be exercised, the educator must be ignorant, intelligent and emancipated. Ignorance means that the educator's intelligence, in the sense of own opinions insights and knowledge, are removed from the pedagogical engagement in order for the intelligence of the student to emerge. The educator must, however, be intelligent and emancipated in the sense that the power of the own intelligence is discovered and exercised.

The educator is ignorant in different ways. In the immediate sense, the educator is ignorant of exactly what has to be learnt and how the learning has to happen. From his experience with the students "he concluded that the act of the teacher who obliges another intelligence to exercise itself was independent of the possession of knowledge ..." (Rancière 2010, 2). The educator is ignorant of the truth in itself and also about the opinion the student will express.

In a second sense the educator suspends his knowledge of the object of attention so as not to transmit any of it. This knowledge does not play, in Socratic mode, an invisible guiding role in the student's acquisition of the same. The student has to find his/her own opinion unmediated by the opinion of the educator. The educator is not the source of knowledge or the judge for legitimate knowledge.

Furthermore, the educator is ignorant of the notion that inequality (Rancière 2010,4) exists and is therefore emancipated from its strictures. This includes for Biesta $(2017,64)$ the Marxist insight into the objective state of oppression concealed by ideology. Since the educator is ignorant of the "true causes" of oppression he or she cannot illuminate the student (contra the Critical Pedagogue). This also applies to the educator committed to emancipation from coloniality. Such an educator may have personal and academic insight into coloniality, but is ignorant of the particular conditions of oppression and of how a particular student should become emancipated. This notion of ignorance is not consistently present among decolonial authors. While Wa Thiong'o, for example, focuses on the content of teaching, he believes that the material must still be interpreted for the students. The only question for him is who does the interpretation, An African or a non-African (Wa Thiong'o 1987, 101). In this case the colonial master is simply replaced with a postcolonial one.

Although the "schoolmaster" is "ignorant" $s /$ he is intelligent in the sense that the equality of the student's intelligence is recognised as well as their need to make their own sense. Such an educator knows when intelligence is exercised and what kind of intelligence (in the form of a text or a task) students should engage with. Such an educator also knows when will, courage and attentiveness are absent. 


\section{Will, courage and attention}

The educator stops explicating to allow students to learn not only by themselves but also for themselves. Explication kills both the ability and the will to learn. The important question is then how learning would happen in the absence of structured teaching. How is valuable learning possible without carefully designed and controlled processes? It would be a big mistake to undervalue the pedagogical role of the educator on the basis of the notions of equal intelligence and the "ignorant schoolmaster". No justification could be found within Rancière's views for the absence or lack of attention of the educator. The ignorant educator is not the absent educator.

Since intelligence is driven by the will, the emancipatory pedagogical relation is not characterised by relations of intelligence, but by that of will. The authority and power of the intelligence of the educator is replaced by the power and authority of the will. The educator wills the will of the student. But, however strong the will of the educator is (which may entail forms of coercion), emancipatory education is not possible without the will of the student. This is the dilemma of any pedagogy that aims at emancipation which could only come from the will and desire of the student. No educator, however emancipated or strong-willed, could liberate students. The best such an educator could do is to create the conditions in which the will of the student could be awakened and exercised.

In spite of the axiom of equal intelligence, the student still has to realise his/her emancipation. Emancipation could not be bestowed on another but could only be exercised and verified (Rancière 1991, 137) through the courageous, persistent and attentive application of the will. While Rancière assumes equality of intelligence, he also assumes generally the weakness of will, lack of courage and the absence of attention.

The emancipatory pedagogical context consists of the creation of conditions for the exercise of intelligence. The conditions are laid out in Rancière's narrative of Jakotot who gave students a Flemish/French parallel text by means of which they had to learn French.

"The book prevents escape. The route the student will take is unknown. But we know what he cannot escape: the exercise of his liberty. We know too that the master won't have the right to stand anywhere else - only at the door. The student must see everything for himself, compare and compare, and always respond to a three-part question: what do you see? what do you think about it? what do you make of it? And so on, to infinity." (Rancière 1991, 23).

Various aspects of the pedagogical context transpire from this. The book refers to the "object" (Vlieghe 2016) of attention, or educational task from which the student cannot escape. The only way to escape is, paradoxically, to exercise liberty, to use the own intelligence to engage with 
the task by translating the text that constitutes "seeing for yourself". The only legitimate place for the educator is to guard the metaphorical escape door. Students are not allowed to stop asking questions, or to find easy answers, or to accept someone else's explanations (particularly those of the colonist, or of the "expert"). Students are not allowed to say that they do not understand, or that something is too complicated, or to take flight into the fear for freedom (Fromm 1965).

The educator wills them to find answers for themselves which only they can with the necessary will, courage and persistence. The educator does not tell them, but continually asks what they think or what sense they make. These questions are without end since the truth remains beyond the reach of language. In the process students could discover their own intelligence and the power of the newly founded knowledge.

In his description of the role of the educator Rancière does not shy away from the language of authority, coercion and compulsion. The "impossible" (Edwards 2008) hope is that the will would emerge within students to emancipate themselves. The idea that freedom could be bestowed is self-contradictory. The biggest struggle for freedom is with the self to ask anew, ad infinitum, what there is to see, what one thinks and how one understands it. "The obstacle stopping the abilities of the ignorant one is not his or her ignorance, but the consent to inequality. The ignorant one holds the opinion that intelligences are not equal." (Rancière 2010, 5). The educator has a very important role while guarding the door:

"These are in fact the master's two fundamental acts. He interrogates, he demands speech, that is to say, the manifestation of an intelligence that wasn't aware of itself or that had given up. And he verifies that the work of the intelligence is done with attention, that the words don't say just anything in order to escape from the constraint." (Rancière 1991, 29).

It is important for students to talk since speech makes intelligence visible to the self and to others. Verification does not refer to epistemic criteria but whether attention was given to the task by the student. Students have to pay attention and focus on the intellectual demand of the task. Such demands are not met when they just say anything. Such speech in the context of coloniality is likely to draw on dominant discourses and rhetorical phrases. The will of the educator also encourages the student not give up on the demands and the continual quest.

"The emancipatory teacher's call forbids the supposed ignorant one the satisfaction of what is known, the satisfaction of admitting that one is incapable of knowing more. Such a teacher forces the student to prove his or her capacity, to continue the intellectual journey the same way it began." (Rancière 2010, 6). 
In order to develop the will of the student, the object of attention should be worthy of the phrase "everything is in everything" by opening up intelligence. Whereas colonial education does not want to expose the colonised minds to "dangerous, undesirable, and unacceptable moral and political influences" (Wa Thiong'o 1987, 69) these kinds of texts are most likely to open up possibilities for students to think for themselves.

\section{Towards a pedagogy for decoloniality}

The emancipatory pedagogy of Rancière addresses the problem of power and freedom by separating the power of intelligence from the power of the will. Only when the will of the student is activated through the intervention of the educator, could the student start to exercise freedom. The fact that power and authority are not exercised over the intelligence of the student separates Rancière's pedagogy from other emancipatory ones. While the same egalitarian relation is proposed by Freire, the role of the educator is apparently weakened (Galloway 2012, 175). In Critical Pedagogy emancipation is dependent on an external analysis of how consciousness is shaped by power and prevented by ideologies from understanding itself. In these views emancipation is therefore based on the inequality between the unemancipated and the emancipator (Biesta 2017, 55). It rests on the distrust of the experiences and thoughts of the unemancipated. Since Critical Pedagogy assumes inequality, it could not promote equality. The axiom of equal intelligence implies that the oppressed do not need the insights of the critical educator in order to become emancipated. There is no "false consciousness" from which they have to be liberated first in order to see the true mechanisms of oppression, there may only be the absence of the will and the courage to become emancipated.

A decolonial pedagogy could therefore not go the route of Critical Pedagogy. It should also go further than to mainly focus on the negative side of de-coloniality, as is the case for Mignolo $(2011,93)$

"decoloniality seeks to unmask, unveil, and reveal coloniality as an underside of modernity that coexisted with its rhetoric of progress, equality, fraternity, and liberty. It is a particular kind of critical intellectual theory as well as political project which seeks to disentangle ex-colonised parts of the world from coloniality."

A similar reactive response is presented by Ndlovu-Gatsheni $(2015,489)$

"[d]ecoloniality is born out of a realization that the modern world is an asymmetrical world order that is sustained not only by colonial matrices of power but also by pedagogies and epistemologies of equilibrium that continue to produce alienated Africans that are socialized into hating Africa that produced them and liking Europe and America that reject them." 
A decolonial pedagogy based on equal intelligence should also go further than Mignolo's (2011) "epistemic disobedience", which is part of a search in the global South for "independent thought and decolonial freedom". It should also go further than protest. It is clear from the student protests that coloniality does not succeed in producing docile and obedient subjectivities since subjectivities of defiance, initiative, courage and persistence transpired clearly. Although the subjectivities refused the presumption of inequality that allocate to them a second-class citizen role, it does not yet transpire how the asserted equal intelligence is exercised to produce subjectivity differently.

The positive side of a decolonial pedagogy has not yet been well expressed. Decoloniality is not only a reaction against coloniality but rather the performance of a different world. The outcome is uncertain since we cannot know what kinds of worlds would be created through the interplay of equal intelligences. The aim of emancipatory education is captured by Rancière as follows:

"The problem is not to create scholars. It is to raise up those who believe themselves inferior in intelligence, to make them leave the swamp where they are stagnating - not the swamp of ignorance, but the swamp of self-contempt, of contempt in and of itself for the reasonable creature. It is to make emancipated and emancipating men.” (Rancière 1991, 101, 102).

\section{CONCLUSION}

The protesting students felt the high cost of freedom, and the risk and danger of thinking for themselves by disobeying coloniality and by hoping for a different future. In this process they verify their equality that is denied in pedagogical relations. While students play a crucial role in the decolonial struggle they cannot do so unaided by emancipatory educators. The educational task is not to teach the students about their struggles, the ways they are colonised, or the world to come, but to ensure that their quest for intellectual emancipation persists in fidelity to the protest events. The interrogations of the educator prompt students to persistently think the unfamiliar and to challenge all colonising knowledges. Their responses come from their openness to and interactions with others. The educator verifies that the student relied on his/her own intelligence without relying on any of these others. The processes of interrogation and verification aim to peel the deeply embedded layers of coloniality through which compliant subjectivities are produced. These pedagogical processes are based on the realisation that decolonisation can only come from the colonised themselves. This resonates with Freire's $(2005,44)$ view that "the great humanistic and historical task of the oppressed [is] to liberate themselves and their oppressors as well". The danger exists that the effect and significance of 
decolonial events such as the 2015/6 student protests may disappear if it is not kept alive.

If the intellectual equality of the colonised is accepted, the world to become could not be expected to fit into existing frames as suggested by some anti-oppressive pedagogies. The pedagogy of equal intelligence is radical in the sense that the insights students may gain and the worlds made possible are beyond the knowledge and control of any educator. The novelty is particularly important for a decolonised pedagogy which attempt to escape from the stultification of coloniality. For Rancière $(2010,9)$ "all emancipation can promise is to teach people to be equal in a society ruled by inequality and by the institutions that 'explain' such inequality".

The purpose of this article is not only to introduce the concept of equal intelligence and to relate it to the concept of decoloniality, but also to affect educational experimentations and research. By affirming the importance of theories and concepts in research (Jackson and Mazzei 2012), the conceptual link between decoloniality and equal intelligence opens new avenues. Research and experimentations that start with the presumption of equality is likely to produce different results. In this process the presumption of equal intelligence is verified when reality is performed differently.

\section{REFERENCES}

Anwaruddin, S. M. 2015. Pedagogy of ignorance. Educational Philosophy and Theory 47(7): 734-746. http://dx.doi.org/10.1080/00131857.2014.914879

Arendt, H. 1998. The human condition. $2^{\text {nd }}$ Edition. Chicago: University of Chicago Press.

Biesta, G. J. J. 2017. Don't be fooled by ignorant schoolmasters: On the role of the teacher in emancipatory education. Policy Futures in Education 15(1): 52-73.

Bingham, C. and G. J. J Biesta. 2010. Jacques Rancière: Education, truth, emancipation. London: Continuum.

Callon, M. and B. Latour. 1981. Unscrewing the big Leviathan: How actors macro-structure reality and how sociologists help them to do so. In Advances in social theory and methodology: Toward an integration of micro- and macro-sociologies, ed. K. Knorr-Cetina and A. V. Cicourel, 277-303. Routledge and Kegan Paul.

Dabashi, H. 2015. Can non-Europeans think? London: Zed Books.

Edwards, R. 2008. Education - an impossible practice. Scottish Educational Review 40(1): 4-11.

Fanon, F. 2008. Black skin, white masks. Translated by C. L Markmann. London: Pluto Press.

Freire, P. 2005. Pedagogy of the oppressed. Introduction by D. Macedo. Translated by M Ramos. New York: Continuum.

Fromm, E. 1965. Escape from freedom. New York: Avon Books.

Galloway, S. 2012. Reconsidering emancipatory education: Staging a conversation between Paulo Freire and Jacques Rancière. Educational Theory 62(2): 163-184.

Hallward, P. 2005. Jacques Rancière and the subversion of mastery.

Haraway, D. J. 1988. Situated knowledges: The science question in feminism and the privilege of partial perspective. Feminist Studies 14: 575-599. 
Jackson, A. Y. and L. A. Mazzei. 2012. Thinking with theory in qualitative research. Viewing data across multiple perspectives. London: Routledge.

Langa, M. (Ed.). 2017. \#Hashtag. An analysis of the \#Feesmustfall movement at South African universities. Johannesburg: Centre for the Study of Violence and Reconciliation. https://www.africaportal.org/publications/hashtag-an-analysis-of-the-feesmustfall-movement-atsouth-african-universities/

Le Grange, L. 2016. Decolonising the university curriculum. South African Journal of Higher Education 30(2): 1-12. http://dx.doi.org/10.20853/30-2-709

Mabasa, K. 2017. The rebellion of the born unfrees. Fallism and the neo-colonial corporate university. Strategic Review for Southern Africa 39(2): 94-116.

Maldonado-Torres, N. 2007. On the coloniality of being. Cultural Studies 21(2): 240-270.

Mbembe, A. J. 2016. Decolonizing the university: New directions. Arts \& Humanities in Higher Education 15(1): 29-45. https://doi.org/10.1177/1474022215618513

Mignolo, W. D. 2009. Epistemic disobedience, independent thought and de-colonial freedom. Theory Culture \& Society 26(7-8): 1-23.

Mignolo, W. D. 2011. The darker side of Western modernity: Global future, decolonial options. Durham: Duke University Press.

Ndlovu-Gatsheni, S. J. 2015. Decoloniality as the future of Africa. History Compass 13(10): 485-496.

Quijano, A. 2000. Coloniality of power, eurocentrism, and Latin America. Nepantia: Views from the South 1(3): 533-580.

Rancière, J. 1991. The ignorant schoolmaster. Five lessons in intellectual emancipation. Translated by K. Ross. Stanford: Stanford University Press.

Rancière, J. 2010. On ignorant schoolmasters. In Jacques Rancière. Education, truth, emancipation, ed. C. Bingham and G. J. J Biesta. London: Continuum.

Rancière, J. 2012. Proletarian nights. The workers' dream in Nineteenth-Century France. Translated by J. Drury. Updated edition. London: Verso.

Said, E. W. 2003. Orientalism. London: Penguin.

Santos, B. de S. 2014. Epistemologies of the South. Justice against epistemicide. London: Routledge.

Simons, M. and J. Masschelein. 2011. Rancière, public education and the taming of democracy. Chichester, Sussex: Wiley-Blackwell.

Vlieghe, J. 2016. Rethinking emancipation with Freire and Rancière: A plea for a thing-centred pedagogy. Educational Philosophy and Theory, 917-927. http://dx.doi.org/ 10.1080/00131857.2016.1200002

Wa Thiong'o, Ngugi. 1987. Decolonising the mind. The politics of language in African literature. Harare: Zimbabwe Publishing House.

Wa Thiong'o, Ngugi. 1993. Moving the centre. The struggle for cultural freedoms. Nairobi: EAEP. 